\title{
PENGRAJIN TIKAR PANDAN DI DESA ALUE O IDI RAYEUK
}

\author{
Tengku Winona Emelia
}

Jurusan Pendidikan Bahasa Inggris, Fakultas Keguruan dan Ilmu Pendidikan, Universitas Muhammadiyah Sumatera Utara, Medan, Indonesia

*Penulis Korespondensi: tengkuwinonaemelia@gmail.com

\begin{abstract}
Abstrak
Pengrajin tikar pandan yang berada di desa Alue O, Idi Rayeuk Aceh Timur, telah berhasil memproduksi berbagai kerajinan yang terbuat dari tikar pandan. Namun dalam perkembangannya motif atau disain kerajinan tikar pandan perlu diberikan pelatihan motif dan disain baru yang lebih variatif sehingga hasil kerajinan usaha kecil menengah ini dapat bersaing di pasar lokal, selanjutnya memberikan pelatihan pembukuan guna mengembangkan industri rumah tangga yang dikerjakan ibuibu pengrajin di sekitar desa Alue O Idi Rayeuk. Dengan kapasitas yang dimiliki sudah selayaknya, Universitas Muhammadiyah Sumatera Utara memberikan peran yang sangat esensial guna menciptakan lebih banyak lagi pengrajin-pengrajin tikar pandan yang dapat mengaplikasikan bentuk motif dan disain tikar pandan. Jika ditinjau dari jumlah dan kemampuan tenaga pengrajin yang dimiliki pengrajin yang ada sudah cukup untuk melayani pasar, permasalahan yang sangat mendasar yang dihadapi oleh pengrajin adalah pengembangan disain dan motif kreatif yang mempunyai karakteristik yang berbeda dari daerah lain. Tujuan kegiatan pengabdian IbM ini adalah untuk membantu mengembangkan disain dan motif baru. Metode yang dilakukan dalam kegiatan IbM adalah pendampingan dan penyuluhan cara melakukan, pengembangan model dan disain, Hasil kegiatan pengabdian IbM ini berupa (1) disain tas, (2) disain dompet.
\end{abstract}

Kata kunci: Pengrajin tikar pandan, disain, motif.

\begin{abstract}
Pandan Craftsman mats located in the village of Alue O, Idi Rayeuk East Aceh, has managed to produce various handicrafts made of pandan mats. However, in the development of the motive or design of pandan mats handicrafts, it is necessary to provide new motives and designs that are more varied so that the handicrafts of small and medium enterprises can compete in the local market, then provide bookkeeping training to develop the household industry which is done by the mothers of craftsmen around the village Alue O Idi Rayeuk. With the capacity that is owned by the University of Muhammadiyah North Sumatra provide a very essential role to create more pandan mats craftsmen who can apply the form of motifs and pandan mat design. If viewed from the amount and ability of craftsmen owned by existing craftsmen is enough to serve the market, the very fundamental problem faced by artisans is the development of design and creative motives that have characteristics different from other regions. The purpose of IbM's devotion is to help develop new designs and motifs. The methods undertaken in IbM activities are mentoring and counseling on how to perform, model development and design. The results of IbM service activities are (1) bag design, (2) wallet design.
\end{abstract}




\section{PENDAhuluan}

Indonesia dengan keaneka ragaman budaya dikenal oleh dunia lewat berbagai karya seni yang perlu tetap dikembangkan dan dilestarikan. Keanekaragaman merupakan warisan budaya (cultural heritage) berupa warisan budaya benda dan tak benda (tangible and intangible cultural heritage). Warisan budaya berupa seni patung, seni ukir dan seni kerajinan, aneka ragam batik termasuk warisan budaya benda (tangible), sedangkan seni tari, seni musik dan lainnya, termasuk kategori tak benda (intangible). Salah satu seni kerajinan yang berkembang di Indonesia adalah kerajinan menganyam tikar yang berbahan baku pandan duri, kerajinan ini berkembang di beberapa wilayah Indonesia termasuk wilayah Aceh. Kebudayaan Aceh merupakan salah satu yang memperkaya khasanah budaya negeri kita.Selain taritariannya yang terkenal,seni berupa kerajinan sulaman khas daerah aceh yang kaya warna juga merupakan unsur etnik dalam kebudayaan aceh yang telah ada sejak dahulu kala.

Namun demikian, dalam perkembanganya, kebudayaan berupa karya seni termasuk seni kerajinan kurang diminati dengan baik terutama oleh generasi muda Indonesia. Hal ini dapat dilihat dari kurangnya apresiasi dan minat para generasi muda akan pengetahuan maupun kebudayaan lewat karya seni kerajinan itu sendiri. Dengan kapasitas yang dimiliki sudah selayaknya Universitas Muhammadiyah Sumatera Utara lewat lembaga Pengabdian pada Masyarakat memainkan peran penting untuk turut menciptakan lebih banyak lagi pengrajin-pengrajin kerajinan khas daerah ,untuk menggali dan mengembangkan produk budaya yang mengandung nilai-nilai filosofis dengan mengangkat lokalitas daerah dalam wujud karya seni, dikarenakan karya seni berupa kerajinan merupakan hasil pendidikan ketrampilan yang tentu saja memerlukan nilai-nilai estetika dan ketrampilan yang melatih kesabaran guna menghasilkan produk berkualitas. Peran pendidikan dalam menunjang kemajuan pada setiap bidang kehidupan, tidak dapat dipungkiri lagi. Termasuk dalam dunia seni, peran teknologi informasi memiliki tempat yang strategis untuk menunjang proses kegiatan belajar mengajar di kelas perlu dikembangkan lewat pengabdian di tengah masyarakat guna mengaplikasikan dan mentransfer pengetahuan. Saat ini penerapan kearifan nilai-nilai budaya lokal dalam kehidupan masyarakat Indonesia, yang dulunya sangat dijunjung tinggi ,dewasa ini nampaknya semakin memudar. Indonesia menghadapi beberapa masalah mengenai perebutan hak cipta oleh negara lain.

Kebudayaan kita yang merupakan warisan nenek moyang bangsa Indonesia perlu diiventarisasi hasil karya seninya untuk dipatenkan sebagai produk budaya yang memiliki hak kekayaan intelektual bangsa Indonesia. Pada saat ini kurangnya apresiasi masyarakat kita akan karya seni budaya merupakan permasalahan klasik dimana belum berkembangnya wadah yang dapat menampung keingintahuan masyarakat akan hasil kriya seni sehingga perlu dikemas secara edukatif dan informatif agar masyarakat terutama generasi muda akan tertarik untuk sekedar datang dan menikmati fasilitas tersebut. Peran pergururan tinggi sebagai wadah pembinaan pengrajin dan pengusaha yang bergerak di bidang kerajinan tentunya sangat diperlukan. Perlunya penginventarisasi dan identifikasi potensi daerah lewat penelitian dan pengabdian akan mampu menghasilkan kebijakan-kebijakan yang tepat sasaran. Adanya pelatihan dan pendampingan pendidikan yang bersifat teknis dan non teknis sangat diperlukan agar kualitas produksi dari usaha kecil skala rumah tangga mampu memberikan nilai lebih pada produk yang dihasilkan. Minimnya tingkat pendidikan ibu-ibu pengrajian di Idi Rayeuk tentunya merupakan keterbatasan dalam berinovasi yang memerlukan pendampingan untuk mengembangkan, motif, disain, dan hasil produksi yang berterima pasar. 
Peningkatan produktifitas harus diimbangi dengan efisiensi dari pengolahan produk itu sendiri, sehingga menghasilkan mutu yang lebih baik. Tantangan kerajinan cukup besar terutama pengembangan hasil kerajinan masuk ke lini-lini usaha lain, harus ada sinergi supaya kerajinan merupakan bagian penting perekonomian daerah, karena nilai tambah benda terjadi setelah mendapat sentuhan lewat adanya industri kreatif dan penerapan teknologi. Pada saat ini para ibu di Idi Rayeuk yang mayoritas ibu rumah tangga dengan pendidikan yang rendah mampu menghasilkan produk kerajinan disesuaikan dengan permintaan yang ada. Para ibu pengrajin tikar pandan perharinya bisa menghasilkan dua sampai tiga jenis produk dan dan itu sangat tergantung dari jenis dan ukuran produksi yang dibuat, Untuk pemasaran tikar pandan dikatakan oleh ketua kelompok adalah pesanan individu utamanya ibu rumah tangga atau pedagang kerajinan yang mempunyai toko souvenir kerajinan di wilayah Aceh.

Prospek pengrajin tikar pandan sebenarnya cukup baik bila terus dibina dan dikembangkan. Proses pembuatan produk kerajinan tikar ini mulai dari awal sampai berupa produk jadi masih dilakukan secara konvensional hasil dari warisan turun temurun dan para pengrajin tetap menggunakan bahan baku dari lingkungan sekitar. Untuk itu perlunya pengembangan dan inovasi berupa motif baru, teknik baru untuk asesoris pewarnaan. Dikarenakan para ibu pengrajin adalah ibu rumah tangga yang minim informasi akan motif atau teknik yang baru, seperti di daerah lain misalnya yang ada di Jawa. Diperlukan adanya pendampingan untuk edukasi kerajinan (craft education), salah satu tahapan dari pengabdian ini adalah mengenalkan teknik decoupage. Decoupage berasal dari bahasa Perancis, Découper, artinya memotong. Decoupage adalah seni menghias suatu objek dengan menempelkan kertas tissue ke objek tersebut. Kerajinan decoupage ini sudah populer di mancaneraga terutama di Eropa. Tissue yang digunakan ini memang sedikit berbeda dengan tissue yang kebanyakan kita temukan. Tissue ini biasa disebut servietten. Kerajinan decoupage ini sudah mulai digemari para anak muda maupun ibu- ibu rumah tangga terutama yang berada di kota-kota besar terutama Jawa. Hasil kreativitas berupa berbagai macam objek, salah satunya berupa tas pandan atau clutch pandan yang diberi sentuhan teknik decoupage.

Hal ini tentunya perlu dikembangkan dan dikenalkan bagi pengrajin tikar pandan yang ada di Idi Rayeuk. Pandan yang tadinya hanya berupa produk konvensional misalnya tikar alas duduk, bisa dikreasikan menjadi sesuatu yang lebih kreatif.

\subsection{Permasalahan}

Kondisi kelompok usaha mitra belum mencapai skala produksi yang maksimal. Sarana dan prasarana yang tersedia di lokasi seperti jaringan internet, saluran telepon belum dimanfaatkan dengan optimal. Terdapat beberapa permasalahan yang dihadapi oleh kelompok usaha mitra, yaitu : (1) Pemasaran kelompok usaha masih bersifat konvensional, penjualan berdasarkan titip jual dan langsung bayar . Kelompok usaha belum memanfaatkan teknologi komputer sebagai sarana pemasaran produk. Akibatnya area pemasaran sangat terbatas (lokal), yaitu Aceh Timur dan sekitarnya. (2) Pembukuan belum tertata dengan baik dan teratur. Kelompok usaha tidak rutin melakukan pencatatan setiap transaksi (pembelian faktor - faktor produksi maupun dalam pemasaran produk). (3) Perhitungan biaya produksi berdasarkan perkiraan dan opportunity cost (biaya peluang) tenaga kerja pemilik maupun anggota keluarga tidak diperhitungkan. Kelompok usaha belum mencatat semua aset yang dimilikinya, seperti jumlah asset setiap jenis produk.

\subsection{Solusi Yang Ditawarkan}

Metode Pendekatan yang ditawarkan untuk mendukung realisasi program IbM. Solusi yang ditawarkan adalah dengan mengadakan pelatihan serta pendampingan membuat disain tikar pandan yang baru dan diberikan dasar dasar pembukuan kewirausahaan bagi pengrajin tikar pandan untuk memotivasi pengrajin dalam berwirausaha,sehingga ibu-ibu rumah tangga yang belum produktif menjadi produktif. 


\subsection{Target Luaran}

Target kegiatan ini adalah pengrajin tikar pandan mampu mengakses informasi dan membuka jejaring pasar lewat internet, dengan mengembangkan teknik decoupage akan didampingi tim IbM bersama-sama pengrajin tikar pandan, ketika program selesai pengrajin mempunyai ketrampilan desain dan teknik baru yang dapat digunakan untuk berkarya dan diharapkan maupun membuka lapangan pekerjaan dengan berwiraswasta dalam bidang seni kerajinan. serta diharapkan tim IbM ibu-ibu rumah tangga disekeliling lingkungan pengrajin juga bisa lebih produktif.

\section{METODE PELAKSANAAN}

Untuk mencapai tujuan dan memberikan solusi permasalahan yang telah dituliskan pada pendahuluan yaitu tentang pengembangan motif, disain, serta pelatihan pembukuan Metode pelaksanaan kegiatan yang dilakukan adalah sebagai berikut 1. Membuat disain tas 2. Membuat disain dompet (clutch) pandan Metode yang dijalankan yaitu:

a) Kesepakatan dengan mitra dalam merencanakan disain motif

b) Melakukan koreksi terhadap pola disain

c) Perhitungan biaya pembuatan dari disain produk

d) Proses pembuatan dilakukan dibawah pendampingan tim Ibm dan mitra

\section{HASIL DAN PEMBAHASAN}

\subsection{Hasil}

Hasil yang didapat dalam kegiatan antara tim pelaksana IbM UMSU dengan mitra pengrajin tikar pandan di Kapupaten Aceh Timur adalah (1) Tas tikar pandan (2) dompet (clutch) tikar pandan

\subsection{Pembahasan}

Kerjasama yang terjalin antara tim IbM UMSU dan mitra sangat baik dan saling mendukung. Pada saat pendampingan dan penyuluhan, mitra sangat memperhatikan dan antusias mengikuti. Tim memberikan penjelasan tentang motif dan disain serta pelatihan pembukuan dan memberikan buku-buku motif disain yang sedang berkembang dewasa ini. Semua kegiatan berjalan dengan lancar sesuai yang telah ditargetkan dan disepakati. Penerapan disain dan motif baru yang diberikan dilengkapi dengan pola disain dilengkapi dengan buku-buku berupa pola tas dan dompet yang akan diterapkan berbahan pandan. Pelatihan disajikan secara sederhana dan dapat dengan mudah dipelajari dan dipraktekkan anggota kelompok pembuat tikar pandan. Produk disain dan motif tikar yang dihasilkan secara ekonomis diharapakan diterima pasar dikarenakan sasaran daripada pengembangan produk disain adalah dapat berterima oleh pasar. Produk disain yang dihasilkan diharapkan mempunyai nilai guna untuk kegiatan khalayak sasaran yakni ibu rumah tangga, dengan disain yang dirancang lebih modern, dan tetap menampilkan kekhasan dari ornamen lokalitas daerah yakni daerah Aceh khususnya ornamen Aceh Timur. Dengan adanya disain motif baru diharapkan bisa memberikan kemudahan bagi pengrajin pandan untuk meningkatkan kualitas produksi dan kapasitas produksi, sehingga keuntungan bertambah.

\section{KESIMPULAN}

Berdasarkan serangkaian kegiatan yang telah dilaksanakan, beberapa hasil kegiatan yang telah memberikan solusi permasalahan IbM pengrajin tikar pandan bekerjasama dengan tim IbM UMSU Medan adalah sebagai berikut.

1. model tas berbahan pandan 2. model dompet berbahan pandan 3 . pengembangan dalam pemasaran yang memerlukan strategi pemasaran lewat internet dengan membuat website hasil kerajinan tikar Idi Rayeuk dan perlunya sosialisasi dengan departemen pendidikan di lingkungan sekolah yang ada disekitar desa pengrajin melalui edukasi kerajinan (educraft) agar generasi muda mengenal dan mencintai seni budaya daerah. Tantangan kerajinan cukup besar terutama pengembangan hasil kerajinan masuk ke lini-lini usaha lain, harus ada sinergi agar kerajinan menjadi bagian penting penunjang perekonomian daerah, karena nilai tambah sebuah hasil karya berupa benda terjadi setelah mendapat sentuhan industri kreatif dan teknologi. Strategi pemasaran dalam jaringan perlu dilakukan dan perlunya edukasi tentang kerajinan bagi generasi muda secara formal disekolah. 


\section{UCAPAN TERIMAKASIH}

Secara khusus kami mengucapkan banyak terimakasih kepada: (1) Direktorat Riset dan Pengabdian Masyarakat, Direktorat Jenderal Penguatan Riset dan Pengembangan Kementerian Riset, Teknologi, dan Pendidikan Tinggi yang telah memberi kesempatan dan dukungan dananya. (2) Lembaga Pengabdian kepada Masyarakat Universitas Muhammadiyah Sumatera Utara (3) Mitra pengrajian tikar pandan Idi Rayeuk Aceh Timur (4) LPM Unimed, dan semua pihak yang telah membantu dalam kegiatan ini yang tidak bisa kami sebutkan satu persatu.

\section{DAFTAR PUSTAKA}

Amirul Hadi.2010 Aceh: Sejarah, Budaya, dan Tradisi. Yayasan Obor Indonesia

Balai Besar industri Kerajinan Batik. 1986. Sejarah Industri Anyaman Indonesia. Yogyakarta. Departemen Perindustrian Badan Penelitian dan Badan Pengembangan Industri Kerajinan Batik.

Djelantik, A.A.M.1999. Estetika Sebuah Pengantar. Bandung: Masyarakat Pertunjukan Indonesia.

Iva Hardiana. 2016. 55 Kreasi Decoupage dalam Berbagai Media: Indonesia: Gramedia Pustaka Utama

Kaleka N dan Edi Trihartono, Kerajinan Daun Pandan.Jakarta. Arcita

Margiono, Fauriah. 2005 Ketrampilan dan Kerajinan Tangan untuk Home Industri.Pontianak YKT.

Somantri, Hendi.2007. Memahami Akuntansi SMK Seri A. Bandung: Armico.

Siagian, Sondang. 2002. Kiat Meningkatkan Produktivitas Kerja. Edisi I, Rinneka Cipta, Jakarta.

Sulasmi, Darma Prawira. 1989. Warna Sebagai Salah Satu Unsur Seni dan Desain. Jakarta: Departemen Pendidikan dan Kebudayaan.

V.Wiratna Sujarweni. 2016. Pengantar Akuntansi. Yogyakarta: Pustaka Baru Press.

Wulandari, Ratna, 1999. Alternatif Pengembangan Bisnis Skala Kecil, Visi Edisi VIII, UNIKA, Kota Semarang. 